Simbiosis Mutualisme Perpustakaan dengan Media Cetak sebagai Upaya Membudayakan Membaca dan Menulis bagi Masyrakat Muhammad Rohmadi

- Faktor Pengembangan dan Isu dalam Masalah Karier Pustakawan Masriyatun

Menguak Informasi via Alexa.com sebagai Evaluasi Menuju Optimalisasi

- Keberaksesan terhadap Perpustakaan dan Institusinya Wiji Suwarno

Profesionalisme Pustakawan dalam Layanan Informasi SriAnawati

Public Space dan Private Space: Posisi Strategis Perpustakaan dalam Mendukung

Pembelajaran Kolaboratif Purwani Istiana

Mewujudkan World-class Professionalism of Librarians di Era Library Mobile

Yuni Nurjanah

- Tantangan dan Kesiapan Pustakawan di Era Digital Dian Hapsari

Formulasi Strategi Membangun Eksistensi Perpustakaan Perguruan Tinggi

(Studi UPT Perpustakaan UNS Tahun 2015) RiahWiratningsih

Optimalisasi Perpustakaan Desa dalam Rangka Meningkatkan Pendidikan Masyarakat Bambang Hemanto

Optimalisasi Layanan Perpustakaan Perguruan Tinggi melalui Pemanfaatan Social

- Media Networking sebagai Media Komunikasi antara Perpustakaan dan Pemustaka Haryanto

Rekonstruksi Budaya Hukum Masyarakat dalam Pemulihan Pascakonflik Etnis Madura dan Melayu di Kabupaten Sambas 


\section{Jurnal \\ Pustaka Ilmiah \\ Jurnal Ilmiah UPT Perpustakaan UNS}

Jurnal Pustaka Ilmiah (JPI) sebagai media kreasi para pustakawan, guru, dosen, dan praktisi dalam pengembangan profesi secara berkelanjutan. Berbagai ide dan gagasan kreatif menjadi bahan kajian yang diimplementasikan dalam berbagai model pengembangan bahan pustaka, baik cetak maupun online. Kreativitas menjadi akar pengembangan ilmu pengetahuan sepanjang hayat dengan berbagai model pengembangan budaya literasi di perpustakaan. Keindahan dan kecermatan dalam sebuah tulisan ilmiah dan nonilmiah akan dapat direalisasikan secara nyata oleh sumber daya manusia untuk menghasilkan SDM yang unggul dan kreatif dengan membaca dan menulis untuk menyinari dunia. Budaya literasi menjadi upaya untuk pengembangan dan pemberdayaan perpustakaan sebagai pusat sumber belajar untuk mendukung tri dharma perguruan tinggi.

\section{SUSUNAN REDAKSI JURNAL PUSTAKA ILMIAH UPT PERPUSTAKAAN UNS}

Penanggung Jawab

Ketua Redaksi

Wakil Redaksi

Sekretaris

Penyunting Ahli
: Dr. Muhammad Rohmadi, M.Hum.

: Dra. Tri Hardiningtyas, M.Si.

: Haryanto, M.IP.

: Bambang Hermanto, S.Pd., M.IP., Henny Perwitosari, A.Md.

: 1. Dr. Muhammad Rohmadi, M.Hum. (Universitas Sebelas Maret);

2. Drs. Widodo, M.Soc.Sc. (Universitas Sebelas Maret);

3. Drs. Harmawan, M.Lib. (Universitas Sebelas Maret).

: Daryono, S.Sos., M.IP.; RiahWiratningsih, S.S., M.Si., Dinar Puspita Dewi, S.Sos., M.IP.; Sri Utari, S.E.

: Nurul H., A. Md.; Novi Tri Astuti, A.Md.

: Aji Hartono, A. Md.; Agus Sriyono, A.Md.; Aris Suprihadi, S.IP.

\section{DITERBITKAN OLEH UPT PERPUSTAKAAN UNS}

REDAKSI JURNAL PUSTAKA ILMIAH

Alamat: Jl. Ir. Sutami 36A Kentingan, Surakarta 57126

Telp./Fax.: (0271) 654311; email: jurnal.pustaka.ilmiah@gmail.com 


\section{PENGANTAR REDAKSI}

Salam pustaka. Dengan rasa syukur kepada allah swt. Segenap redaksi Jurnal Pustaka Ilmiah (JPI) mengucapkan banyak terima kasih kepada para penulis yang telah berkontribusi untuk penerbitan perdana JPI. Dengan terbitnya JPI ini berarti UPT Perpustakaan UNS telah memiliki media penulisan bagai para pustakawan, dosen, tenaga kependidikan, guru, dan praktisi untuk menuangkan ide dan gagasan kreatifnya secara tertulis.

Dalam penerbitan JPI perdana ini disajikan sepuluh tulisan antara lain: (1) Faktor Pengembangan dan Isu Dalam Masalah Karier Pustakawan (Masriyatun), (2) Menguak Informasi via Alexa.com sebagai Evaluasi Menuju Optimalisasi Keberaksesan terhadap Perpustakaan dan Institusinya (Wiji Suwarno), (3) Profesionalisme Pustakawan dalam Layanan Informasi (Sri Anawati), (4) Public Space dan Private Space: Posisi Strategis Perpustakaan dalam Mendukung Pembelajaran Kolaboratif (Purwani Istiana), (5) Mewujudkan World-class Professionalism of Librarians di Era Library Mobile (Yuni Nurjanah), (6) Tantangan dan Kesiapan Pustakawan di Era Digital (Dian Hapsari), (7) Formulasi Strategi Membangun Eksistensi Perpustakaan Perguruan Tinggi (Studi UPT Perpustakaan UNS Tahun 2015) (Riah Wiratningsih), (8) Optimalisasi Perpustakaan Desa dalam Rangka Meningkatkan Pendidikan Masyarakat (Bambang Hemanto), (9) Optimalisasi Layanan Perpustakaan Perguruan Tinggi melalui Pemanfaatan Social Media Networking sebagai Media Komunikasi antara Perpustakaan dan Pemustaka (Haryanto).

Akhirnya, redaksi JPI mengucapkan banyak terima kasih kepada Kepala UPT Perpustakaan UNS yang telah memberikan dukungan dan memfasilitasi untuk penerbitan JPI. Selain itu, ucapan terima kasih juga disampaikan kepada para penulis, tim redaksi, dan Yuma Pressindo, yang telah mempersiapkan dari awal sampai terbitnya JPI.

Desember 2015

Ketua Redaksi, 


\section{SAMBUTAN}

Dr. Muhammad Rohmadi, M.Hum.

Kepala UPT Perpustakaan UNS

\section{“Jadikalah tulisanmu sebagai cermin kehidupanmu di masa sekarang dan masa depan"}

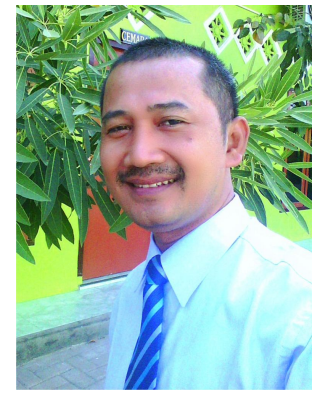

Selamat dan sukses atas diterbitkannya Jurnal Pustaka Ilmiah (selanjutnya disingkat JPI). Sambutan ini diberikan dalam rangka penerbitan perdana JPI. Jurnal ini sebagai media kreativitas dan pengembangan softskill para pustakawan, guru, dosen, dan praktisi untuk menuangkan ide dan gagasan dalam berbagai konteks kehidupan. Berbagai isu terkait dengan pengembangan perpustakan, pusat sumber belajar, pendidikan, dan budaya literasi akan menjadi topik-topik yang disajikan dalama jurnal ilmiah ini.

Diterbitkannya JPI sebagai bukti kepedulian UPT perpustakaan Ilmiah dalam rangka turut berpartisipasi untuk mengembangkan dan membudayakan literasi untuk para pustakawan dan civitas akademika di UNS dan luar UNS. Berbagai model pengembangan softskill menjadi alaternatif untuk membekali dan memperkuat jaringan kerja sama penulisan antarkelembagaan. Dengan demikian, kerja sama antarpustakawan dan pemustaka dapat diwujudkan dengan berbagai model dalam bidang literasi.

Penerbitan JPI sebagai upaya untuk memotivasi semua pustakawan menulis, baik ilmiah maupun nonilmiah. Para pustakawan harus menjadi pionir dalam bidang penulisan. Hal ini sebagai bentuk kepedulian dan keteladaan para pustakawan yang memproses, menyajikan, dan menikmati bahanbahan pustaka cetak dan noncetak di perpustakaan. Ketersedian bahan pustaka akan menjadi bahan paling nyata untuk dikembangkan dalam berbagai model perwujudan teknik peniulisan. Hal terpenting yang harus dimiliki oleh para pustakawan adalah semangat untuk berbagai pengetahuan melalui tulisan.

Kepedulian setiap sumber daya manusia kepada kelembagaan dapat dituangkan dalam berbagai model pengabdian, salah satunya adalah melalui tulisan. Berbagai ide dan gagasan dapat direalisasikan dengan berbagai model bentuk artikel jurnal, buku, modul, monograf, dan lain sebagainya. Para civitas akademika, guru, praktisi harus memiliki keterampilan menulis sebagai bentuk perwujudan pengembangan diri secara berkelanjutan. Berbagai tulisan dan referensi sudah disajikan tetapi masih sangat minim untuk diimplementasikan dalam kehidupan. Banyak orang pandai dalam berbicara tetapi masih sedikit yang menuangkan ide dan gagasannya dalam bentuk tulisan.

Akhirnya, keluarga besarUPT Perpustakaan UNS mengucapkan banyak terima kasih kepada Rektor, Wakil Rektor, pengelola JPI, penulis, dan semua pihak yang telah mendukung penerbitan perdana JPI. Semoga dengan diterbitkannya JPI ini dapat menjadi media untuk menulis para pustakawan, dosen, guru, dan praktisi dalam bidang iptek dan seni. Ucapan terima kasih juga diucapkan kepada percetakan Yuma Pressindo yang telah membantu mempersiapkan dari awal sampai terbitnya JPI ini. Akhirnya, semoga JPI dapat memberikan nilai kemaslahatan untuk umat.

“Berdiri kemudian berbaring sangatlah cepat tetapi tatkala sudah dituliskan akan menjadi kenangan yang taidak terlupakan sepanjang hayat”

Surakarta, Desember 2015 


\section{DAFTAR ISI \\ JURNAL PUSTAKA ILMIAH EDISI 1 VOLUME 1 TAHUN 2015}

Simbiosis Mutualisme Perpustakaan dengan Media Cetak sebagai Upaya Membudayakan Membaca dan Menulis bagi Masyrakat

Muhammad Rohmadi

Faktor Pengembangan dan Isu dalam Masalah Karier Pustakawan.

Masriyatun

Menguak Informasi via Alexa.com sebagai Evaluasi Menuju Optimalisasi Keberaksesan terhadap Perpustakaan dan Institusinya

Wiji Suwarno

Profesionalisme Pustakawan dalam Layanan Informasi

Sri Anawati

Public Space dan Private Space: Posisi Strategis Perpustakaan dalam Mendukung Pembelajaran Kolaboratif

Purwani Istiana

Mewujudkan World-class Professionalism of Librarians di Era Library Mobile

Yuni Nurjanah

Tantangan dan Kesiapan Pustakawan di Era Digital

Dian Hapsari

Formulasi Strategi Membangun Eksistensi Perpustakaan Perguruan Tinggi (Studi UPT Perpustakaan UNS Tahun 2015)

Riah Wiratningsih

Optimalisasi Perpustakaan Desa dalam Rangka Meningkatkan Pendidikan Masyarakat Bambang Hemanto

Optimalisasi Layanan Perpustakaan Perguruan Tinggi melalui Pemanfaatan Social Media Networking sebagai Media Komunikasi antara Perpustakaan dan Pemustaka Haryanto 


\title{
OPTIMALISASI PERPUSTAKAAN DESA DALAM RANGKA \\ MENINGKATKAN PENDIDIKAN MASYARAKAT
}

\author{
Bambang Hemanto \\ bambangh@uns.ac.id
}

\begin{abstract}
ABSTRAK
Perpustakaan desa dapat berperan sebagai lembaga pendidikan nonformal, agen perubahan, dan agen pembangunan bagi masyarakat sekelilingnya. Pendidikan berfungsi untuk mengembangkan kemampuan, membentuk watak dan peradaban bangsa yang bermartabat dalam rangka mencerdaskan kehidupan masyarakat dan bangsa. Perpustakaan desa dapat melakukan optimalisasi perpustakaan dalam mendukung program pemerintah dalam meningkatkan pendidikan masyarakat. Adapun strategi yang dapat dilakukan perpustakaan desa, antara lain: 1) optimalisasi koleksi; 2)penyesuaian jam buka perpustakaan dengan aktivitas masyarakat; 3) mengadakan penyuluhan mengenai manfaat membaca secara berkala; 4) menyediakan taman baca di tingkat RW; 5) mengadakan lomba dengan topik kreativitas masyarakat; 6) mengadakan layanan delivery.
\end{abstract}

Kata kunci: perpustakaan desa, optimalisasi perpustakaan, pendidikan masyarakat

\section{PENDAHULUAN}

Perkembangan teknologi informasi berdampak pada berbagai aspek kehidupan. Setiap orang mendambakan hidup yang layak, mempunyai pendidikan tinggi, dan memperoleh penghasilan yang cukup untuk memenuhi kebutuhan hidup. Pendidikan tidak memandang orang dari ras, suku, kaya miskin, berasal dari pedesaan maupun perkotaan. Pendidikan merupakan kebutuhan pokok manusia dan berpengaruh langsung terhadap perkembangan manusia dalam rangka peningkatan taraf hidup yang lebih baik. Pendidikan mempunyai peran yang sangat penting dalam mencerdaskan kehidupan manusia. Berdasarkan UUD 1945 pasal 31, disebutkan bahwa setiap warga negara berhak memperoleh pendidikan dan pemerintah mewajibkan setiap warga negara mengikuti pendidikan dasar.

Masyarakat yang ingin berkembang dan maju harus mau melakukan perubahan melalui jalur pendidikan formal maupun nonformal.
Namun, tidak semua masyarakat dapat melanjutkan pendidikan ke jenjang yang lebih tinggi atau putus sekolah dengan berbagai alasan, seperti tidak memiliki biaya dan tidak memiliki waktu luang. Hal ini diperkuat dari data laporan tahunan 2012 UNICEF Indonesia bahwa sekitar 2,3 juta atau $42 \%$ anak di Indonesia dengan usia 7 - 15 tahun tidak melanjutkan sekolah pada transisi SD ke SMP.

Perpustakaan mempunyai peran sebagai lembaga pendidikan nonformal, agen perubahan, dan agen pembangunan bagi masyarakat sekelilingnya. Masyarakat dapat memanfaatkan koleksi perpustakaan untuk mencari informasi, mengembangkan ideide kreatif dan inovasi, mencari solusi dalam memecahkan permasalahan, dan mencari informasi mengenai hal-hal baru. Perpustakaan dapat menyediakan fasilitas, sebagai sumber informasi, dan pusat pembelajaran.Perpustakaan dapat mendukung program pemerintah dalam meningkatkan taraf hidup masyarakat melalui 
pendidikan. Dipertegas oleh Sutarno (2006: 68), perpustakaan dengan bahan bacaan yang berisi pendidikan dan informasi dapat menggugah aspirasi, inspirasi, gagasan, dan ide-ide yang cemerlang untuk mengembangkan minat dan bakat masyarakat.

Perpustakaan desa dapat dimanfaatkan oleh pemerintah sebagai sarana pengembangan gerakan membaca. Menurut Sulistyo-Basuki (1999: 75), tujuan perpustakaan adalah menyimpan dan melestarikan khazanah budaya bangsa untuk dapat diturunkan ke generasi berikutnya demi kemajuan manusia.

Berdasarkan uraian di atas, penulis akan membahas persoalan utama yang menjadi topik pada tulisan ini, yaitu strategi apa yang digunakan perpustakaan desa dalam mengoptimalkan perpustakaan dalam rangka meningkatkan pendidikan masyarakat?

\section{PEMBAHASAN}

\section{Peran Masyarakat}

Masyarakat sebagai pengguna perpustakaan merupakan salah satu komponen perpustakaan. Perpustakaan dibangun untuk melayani kebutuhan masyarakat akan informasi. Menurut Sutarno (2006: 18), perpustakaan pada dasarnya milik masyarakat. Sedangkan Sulistyo-Basuki (1999: 75) menyatakan bahwa perpustakaan merupakan bagian dari masyarakat dan diciptakan oleh masyarakat.

Masyarakat dapat berperan aktif dalam pengembangan perpustakaan desa, seperti pengadaan koleksi perpustakaan, peningkatan sarana dan fasilitas,melestarikan perpustakaan, dan pengembangan sumber daya perpustakaan lainnya. Salah satu faktor pendukung dalam keberhasilan perpustakaan desa adalah ada respons yang baik dari masyarakat sekitarnya. Dukungan masyarakat dapat berupa pikiran, dana, maupun pemanfaatan koleksi perpustakaan. Sebaliknya, pihak pengelola perpustakaan harus memperhatikan kebutuhan koleksi yang dibutuhkan oleh masyarakat, seperti dalam pengadaan koleksi perpustakaan. Masyarakat dapat dilibatkan dengan memberikan masukan dan pertimbangan dalam pemilihan koleksi supaya sesuai dengan kebutuhan masyarakat. Hal ini secara otomatis akan membuat masyarakat merasa memiliki perpustakaan dan perpustakaan dapat menjadi sarana pemerintah dalam mewujudkan budaya baca masyarakat.

Hubungan antara masyarakat dan perpustakaan dapat terbentuk dengan harmonis dikarenakan keduanya saling membutuhkan. Menurut Kenretno (2010), perpustakaan membutuhkan kehadiran masyarakat sebagai pengguna perpustakaan yang akan memanfaatkan layanan dan fasilitas perpustakaan, sedangkan masyarakat membutuhkan informasi yang sudah dikelola dan ditata oleh perpustakaan untuk mencari ide, menambah pengetahuan, memecahkan permasalahan, menambah pengalaman, dan meningkatkan keterampilan.

\section{Peran Pemerintah Desa}

Pemerintahan desa mempunyai peranan yang signifikan dalam kelanjutan pengembangan perpustakaan desa. Dukungan dari pimpinan desa mempunyai dampak positif dalam kemajuan dan peningkatan layanan perpustakaan. Pemerintah desa dalam membangun dan mendirikan perpustakaan tentu mempunyai alasan, pertimbangan, dan kebutuhan. Adapun alasan membangun perpustakaan menurut Sutarno (2006: 78), antara lain: 1) perpustakaan merupakan salah satu komponen yang harus ada; 2) untuk memperlancar kegiatan pemerintah; 3) adanya kebijakan dari pimpinan; 4) untuk meningkatkan layanan publik; 5) tersedianya anggaran.

Adapun peran pemerintah desa dalam pengembangan perpustakaan, antara lain: 1) mengalokasikan anggaran untuk pengembangan perpustakaan; 2) meningkatkan sarana dan fasilitas; 3) pengembangan sumber daya 
manusia; 4) mendukung program perpustakaan dalam membumikan budaya baca.

\section{Optimalisasi PerpustakaanDesa}

Perpustakaan sebagai sumber informasi dan pendidikan dapat menjembatani masyarakat yang tidak dapat melanjutkan ke jenjang pendidikan yang lebih tinggi. Selain itu, perpustakaan dapat dimanfaatkan oleh masyarakat yang mempunyai tekad mencari informasi untuk menambah wawasan, pengetahuan, meningkatkan taraf hidup, serta memperoleh ide-ide dalam memecahkan permasalahan yang dihadapi dalam kehidupan sehari-hari. Senada dengan Sutarno (2006) bahwa perpustakaan dengan bahan bacaan yang berisi pendidikan dan informasi dapat menggugah aspirasi, inspirasi, gagasan, dan ide-ide yang cemerlang untuk mengembangkan minat dan bakat masyarakat. Hal ini dipertegas oleh Qolyubi (2003: 7) bahwa perpustakaan memberikan kesempatan kepada masyarakat untuk meningkatkan kehidupan yang lebih baik melalui bahan pustaka yang dibacanya.

Perpustakaan harus proaktif dalam memberikan layanan perpustakaan. Perpustakaan dapat bekerja sama dengan masyarakat dalam memecahkan permasalahan, membuat inovasi-inovasi, dan mencari ide-ide dalam meningkatan pendidikan masyarakat. Adapun strategi yang dapat dilakukan perpustakaan dalam mengoptimalkan perpustakaan desa, antara lain:

1. Optimalisasi koleksi.

Koleksi perpustakaan desa akan dimanfaatkan oleh masyarakat sekitarnya apabila dalam melakukan pengadaan koleksi sesuai dengan program desa dan kebutuhan masyarakat. Untuk mengefektifkan pemanfaatan koleksi, maka sebelum melakukan pengadaan koleksi harus membuat manajemen koleksi sebagai dasar dalam pengadaan koleksi dan minta masukan dari masyarakat sebagai pengguna perpustakaan. Penyajian koleksi juga harus diperhatikan dan dapat disusun berdasarkan subjek untuk mempermudah dalam penelusuran informasi dan temu kembali informasi. Perpustakaan desa harus melakukan kegiatan evaluasi koleksi untuk mengetahui kelemahan dan kekuatan koleksi yang dimiliki. Kegiatan ini dapat berupa kegiatan stock opname dan weddingsyang dilakukan secara berkala.

2. Penyesuaian jam buka perpustakaan dengan aktivitas masyarakat.

Jam buka perpustakaan menjadi salah satu faktor banyak tidaknya pengguna perpustakaan desa. Perpustakaan harus teliti dan bijaksana dalam penentuan jam buka. Perpustakaan harus memperhatikan waktu-waktu luang bagi aktivitas masyarakat. Perpustakaan dapat melakukan survey dan menyebarkan kuisioner kepada masyarakat sebelum menetapkan jam buka perpustakaan.

3. Perpustakaan secara berkala mengadakan penyuluhan mengenai manfaat membaca.

Sebelum melakukan kegiatan penyuluhan manfaat membaca, terlebih dahulu dibuatkan jadwal pelaksanaan. Agar masyarakat tertarik untuk hadir dalam penyuluhan tersebut, perpustakaan dapat menghadirkan tokoh masyarakat atau seseorang yang telah berhasil mencapai cita-cita dan usaha setelah secara rutin melakukan aktivitas membaca. Seperti, 1) Udin Mac lulus STM dan tidak ahli di bidang pertanian menjadi sukses di usaha pertanian dan penggilingan padi berkat membaca majalah; 2) Devi Triasari anak buruh tani dan Suci anak buruh bangunan dapat menyelesaikan kuliah tepat waktu dan lulus dengan IP tertinggi.

Supaya kegiatan penyuluhan manfaat membaca memperoleh simpatik dan dukungan dari masyarakat, perpustakaan dapat memberikan contoh secara langsung manfaat yang diperoleh setelah melakukan membaca. Seperti yang pernah dilakukan pada TBM Intan Pustaka Pasuruan pada tahun 2011 yang dipublikasi pada alamat http://tbmonline. 
blogdetik .com/2011/08/14/membaca-belajarmembuat-kue-penyuluhan-kanker-cervix/ bahwa dalam kegiatan penyuluhan membaca dan ditindaklanjuti dengan praktik secara langsung dalam membuat kue dan penyuluhan tentang kesehatan masyarakat yang mengacu pada koleksi yang ada di perpustakaan.

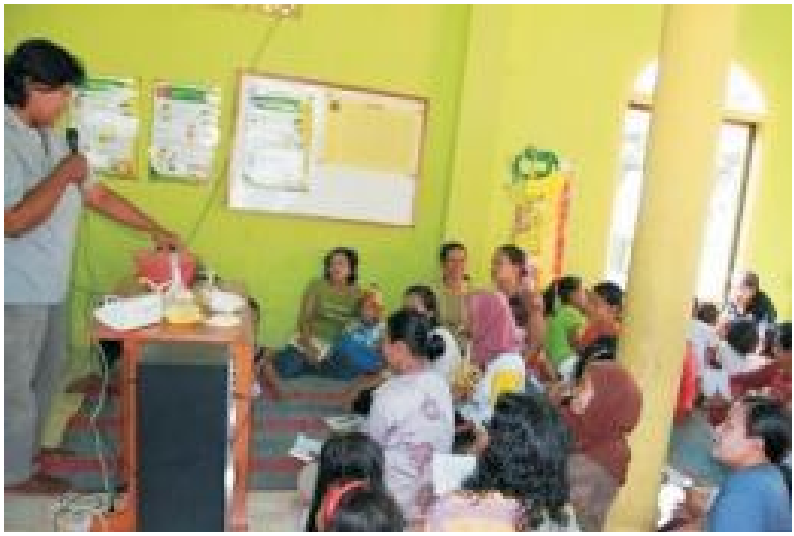

Gambar 1. Cara Membuat Kue (http:// tbmonline.blogdetik.com/2011/08/14/)

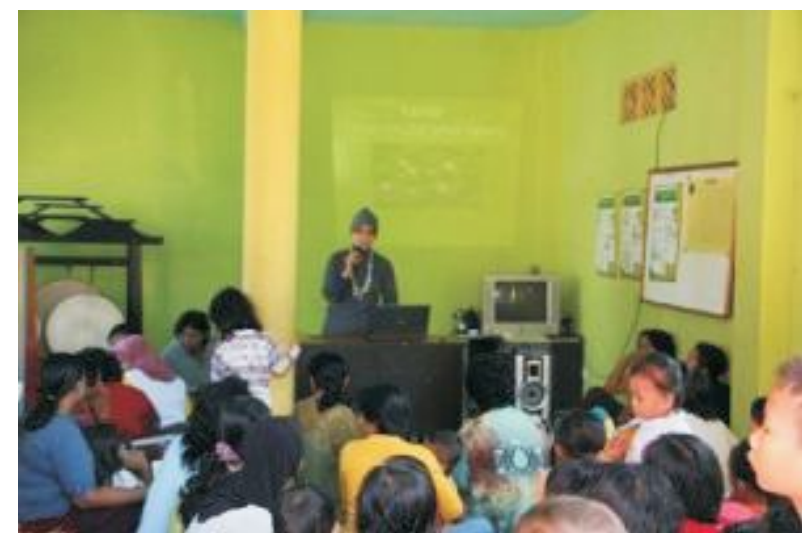

Gambar 2. Penyuluhan Kanker (http:// tbmonline.blogdetik.com/2011/08/14/)

4. Perpustakaan menyediakan taman baca di tingkat RW

Untuk mendekatkan koleksi dengan masyarakat, perpustakaan desa dapat bekerja sama dengan RW untuk membangun taman baca yang ditempatkan di setiap RW. Pengelola taman baca tersebut dapat diserahkan kepada ketua RW dan ketua karang taruna yang telah dibekali dalam pengelolaan perpustakaan. Koleksi perpustakaan yang disajikan di taman baca dapat disesuaikan dengan kebutuhan masyarakat setempat. Untuk mengoptimalkan koleksi, setiap periode dilakukan evaluasi dan dapat ditukarkan dengan koleksi yang ada di RW lainnya.

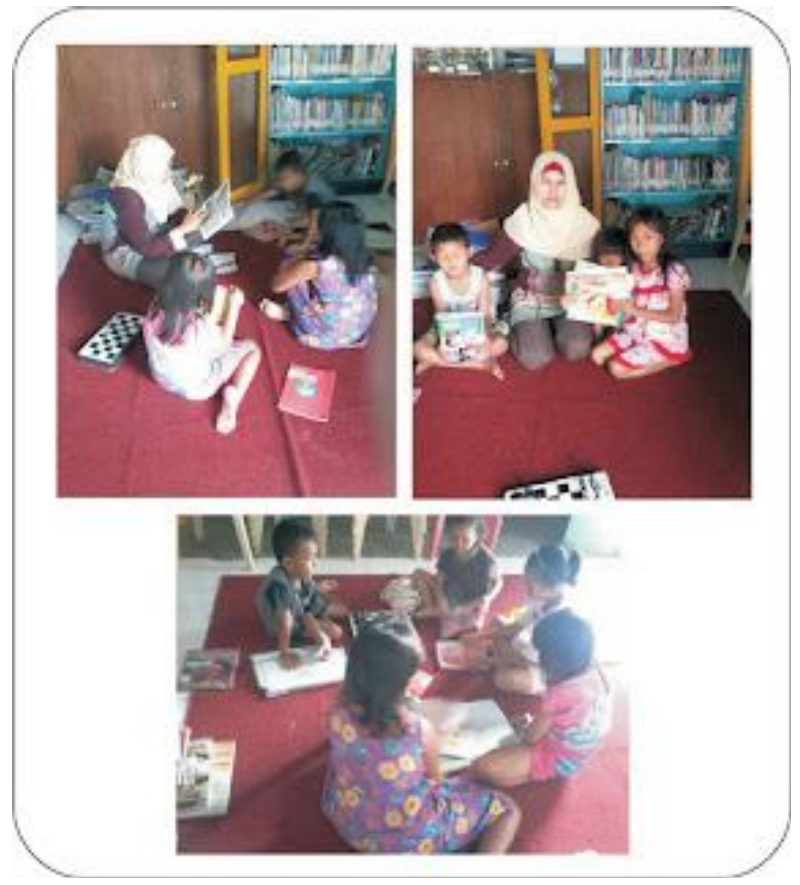

Gambar 3. Taman Bacaan Masyarakat Kelurahan Gunung Sari Surabaya

(http://tbmkecamatandukuhpakissurabaya.blogspot. co.id.)

5. Perpustakaan mengadakan lomba dengan topik kreatifitas masyarakat

Perpustakaan desa dapat membuat program kegiatan lomba kreativitas masyarakat dengan mengambil sumber informasi yang ada di perpustakaan. Kegiatan ini dapat dilaksanakan secara bertahap sebagai berikut.

Tabel 1. Jadwal Kegiatan Lomba

\begin{tabular}{|c|c|l|l|}
\hline No & Tahap & Bulan & \multicolumn{1}{|c|}{ Tema } \\
\hline 1. & I & Maret & $\begin{array}{l}\text { Mengolah } \\
\text { pertanian }\end{array}$ \\
\hline 2. & II & Juni & Budidaya hewan ternak \\
\hline 3. & III & September & $\begin{array}{l}\text { Menyulap barang bekas } \\
\text { menjadi uang }\end{array}$ \\
\hline 4. & IV & Desember & $\begin{array}{l}\text { Mengelola sampah } \\
\text { rumah tangga }\end{array}$ \\
\hline
\end{tabular}

6. Perpustakaan mengadakan layanan delivery

Layanan ini dapat menambahkan jenis layanan delivery. Bagi masyarakat yang tidak dapat datang ke perpustakaan secara langsung, 
dapat memanfaatkan layanan ini. Pengguna perpustakaan dapat memesan melalui telepon, sms, email, dan surat, kemudian pengelola perpustakaan dapat mengantar ke rumah.

Ada beberapa keuntungan yang diperoleh oleh perpustakaan desa apabila melaksanakan layanan delivery ini, antara lain:

a. Perpustakaan mempunyai nilai yang positif di mata masyarakat.

b. Koleksi perpustakaan akan banyak digunakan oleh masyarakat.

c. Dapat meningkatkan mutu layanan perpustakaan.

d. Dapat mempercepat proses peningkatan pendidikan masyarakat.

Adapun kendala yang dihadapi oleh perpustakaan desa dalam menerapkan layanan delivery adalah perpustakaan desa akan membutuhkan tenaga pustakawan yang lebih banyak dan anggaran untuk biaya antarjemput koleksi.

7. Menambah bahan bacaan seperti majalah hiburan, majalah populer dan surat kabar

Untuk menumbuhkan budaya membaca masyarakat, perpustakaan dapat memambah majalah hiburan, majalah populer, dan surat kabar. Hal ini akan menambah wawasan, pengetahuan, dan masyarakat akan mengetahui berita-berita terkini, baik berita tingkat lokal, nasional, dan internasional. Masyarakat tidak ketinggalan informasi dan berita yang sedang berkembang di masyarakat luas.

\section{PENUTUP}

Perpustakaan sebagai sumber informasi dapat menjembatani masyarakat yang tidak dapat melanjutkan ke jenjang pendidikan yang lebih tinggi. Masyarakat dapat memperoleh informasi dalam rangka menambah wawasan, pengetahuan, meningkatkan taraf hidup, serta memperoleh ide-ide dalam memecahkan permasalahan yang dihadapi dalam kehidupan sehari-hari. Perpustakaan harus proaktif dalam memberikan layanan perpustakaan. Perpustakaan dapat bekerja sama dengan masyarakat dalam memecahkan permasalahan, membuat inovasi-inovasi, dan mencari ide-ide peningkatan taraf hidup masyarakat.

Strategi yang dapat digunakan oleh perpustakaan desa dalam mengoptimalkan perpustakaan dalam rangka meningkatkan pendidikan masyarakat adalah mengoptimalkan koleksi, penyesuaian jam buka perpustakaan dengan aktivitas masyarakat, mengadakan penyuluhan mengenai manfaat membaca secara berkala, menyediakan taman baca di tingkat RW, mengadakan lomba dengan topik kreativitas masyarakat dan mengadakan layanan delivery.

\section{DAFTAR PUSTAKA}

Anonim. tt. "Jujur, Berani dan Kreatif: Kunci Sukses Udin di Pertanian”. Diakses pada 3 November

2015, dari http://www.ciputraentrepreneurship.com/agrobisnis/jujur-berani-dan-kreatifkunci-sukses-udin-di-pertanian.

Anonim. tt. "Raih IPK 3,99, Putri Buruh Tani Jadi Lulusan Terbaik UNS". Diakses pada 28 Oktober 2015, dari http://regional.kompas.com/read/2015/06/01/18434131/raih.ipk. 3.99. putri.buruh.tani.jadi.lulusan.terbaik.uns.

Anonim. tt. "Suci Anak Kuli Bangunan Wisudawan Terbaik Unnes". Diakses pada 28 Oktober 2015, dari http://unnes.ac.id/berita/suci-anak-kuli-bangunan-wisudawan-terbaik-unnes/.

Ken Retno. 2010. "Memasyarakatkan Perpustakaan: Peran Perpustakaan Bersama Masyarakat dalam Mewujudkan Budaya Baca”. Diakses pada 18 November 2015, dari http://kenretno. blogspot.co.id/2010/02/perpustakaan-dan-masyarakatditulis_8557.html 
Qalyubi, Syihabuddin. 2003. Dasar-dasar Ilmu Perpustakaan dan Informasi. Yogyakarta: IAIN Sunan Kalijaga.

Sulistyo-Basuki. 1999. Pengantar Ilmu Perpustakaan. Jakarta: Universitas Terbuka.

Sutarno. 2006. Perpustakaan dan Masyarakat. Jakarta: Sagung Seto.

Unicef Indonesia. 2012. “Laporan Tahunan 2012”. Diakses pada 29 Oktober 2015, dari http://www.unicef.org/indonesia/id/UNICEF Annual Report (Ind) 130731.pdf. 